\title{
Dignity and Human Rights: A Reconceptualization
}

\author{
Laura Valentini \\ London School of Economics and Political Science
}

\section{Forthcoming in Oxford Journal of Legal Studies}

\begin{abstract}
Human rights are often defined as entitlements that human beings possess just by virtue of their inherent dignity. This conceptual link between human rights and inherent dignity is as popular as it is unhelpful. It invites metaphysical disputes about what, exactly, endows human beings with inherent dignity, and distracts from the core function of human rights: placing constraints on powerful actors, especially states. In response to this difficulty, I reconceptualize the relationship between human rights and dignity in a way that maximally serves human rights' purpose. I do so by distinguishing between 'inherent dignity' and 'status dignity', and by linking human rights to the latter, not the former. First, I argue that human rights articulate standards for respecting the status dignity of the subjects of sovereign authority, rather than the inherent dignity of human beings qua humans. Second, I suggest that not only individuals but also corporate agents possess status dignity. In particular, states that violate human rights lose their status dignity, thereby becoming liable to interference.
\end{abstract}

Key words: human rights, inherent dignity, status dignity, authority, conceptual analysis.

\section{Introduction}

In recent decades, few ideas have received as much attention as that of human rights. But what, exactly, are human rights? A popular answer characterizes them as entitlements that all human beings possess by virtue of their inherent dignity and that exist independently of legal or social recognition. ${ }^{1}$ This definition, which draws a conceptual link between human rights and dignity, is prominent in scholarly circles, human-rights documents, and political discourse more generally. ${ }^{2}$ For instance, the Universal Declaration of Human Rights (UDHR) of 1948 refers to dignity multiple times, and so do the International Covenant on Civil and Political Rights (1966) and the International Covenant on Economic, Social and Cultural Rights (1966). ${ }^{3}$

Despite its popularity, this way of connecting dignity and human rights is uninformative at best, and counter-productive at worst. It is uninformative because the notion of inherent dignity is opaque. It is often just a placeholder for whichever

\footnotetext{
" I am grateful to Rowan Cruft, Timothy Endicott, Christian List, an anonymous reviewer, and to the participants in the workshop on human rights and human dignity (Chicago, May 2015)—particularly, Adam Etinson, Pablo Gilabert, and Ben Laurence - for detailed comments and discussion.

${ }^{1}$ Dignity is presented either as a necessary ground of human rights, or as a necessary and sufficient ground. I also note that human rights are often defined as rights we hold 'by virtue of our humanity'. I take this expression to be roughly equivalent to appeals to dignity, since humanity, understood as a purely biological feature-i.e., belonging to the species homo sapiens - is not a plausible basis for human rights. See Marcus Düwell, 'Human Dignity: Concepts, Discussions, Philosophical Perspectives' in Marcus Düwell, Jens Braarvig, Roger Brownsword, and Dietmar Mieth (eds), The Cambridge Handbook of Human Dignity: Interdisciplinary Perspectives (Cambridge University Press 2014) 33.

${ }^{2}$ See, e.g., James Griffin, On Human Rights (Oxford University Press 2008) 44-46; John Tasioulas, 'Human Dignity and the Foundations of Human Rights' in Christopher McCrudden (ed), Understanding Human Dignity (Oxford University Press/British Academy 2013) 292, 304; Ronald Dworkin, Justice for Hedgehogs (Harvard University Press 2011) 335; Jürgen Habermas, 'The Concept of Human Dignity and the Realistic Utopia of Human Rights' (2010) 41 Metaphilosophy 464; Pablo Gilabert, Human Dignity and Human Rights (unpublished book manuscript 2016).

${ }^{3}$ For lists of relevant rights documents that cite the idea of dignity, see Doris Schroeder, 'Human Rights and Human Dignity' (2012) 15 Ethical Theory and Moral Practice 323, 325; Christopher McCrudden, 'Human Dignity and Judicial Interpretation of Human Rights' (2008) 19 European Journal of International Law 655.
} 
human attribute grounds human rights, with different philosophical traditions disagreeing on the relevant attribute. ${ }^{4}$ Reference to inherent dignity is also counterproductive, since it pushes the debate on human rights into deep metaphysical waters, and distracts from their political function: placing constraints on the conduct of powerful actors. ${ }^{5}$

In this article, I propose a new understanding of the relationship between dignity and human rights - one that reinforces, rather than undermines, their powertaming function. To do so, I distinguish between dignity as a status, comprising distinctive normative demands (status dignity), and dignity as an inherent property of individuals, which purportedly justifies ascribing a certain status to them (inherent dignity). Status dignity and inherent dignity need not always accompany each other: one may hold status dignity by virtue of possessing properties other than inherent dignity. Definitions of human rights have focused on inherent dignity. I argue that the focus should shift to status dignity - particularly, the status dignity of individuals visà-vis powerful sovereign entities-leaving it open what inherent human property grounds or justifies that status.

My argument proceeds as follows. In Section 2, I set out a general conceptual framework for thinking about dignity, distinguishing between status and inherent dignity, and between passive and active dignity. In Section 3, I defend a version of the 'political' approach to human rights, according to which the primary bearers of the duties correlative to human rights are entities with sovereign authority. In Section 4, I bring the discussions in the previous two sections together, and argue that human rights are standards of status dignity applying to states' treatment of their individual subjects. By failing to respect human rights, states - qua corporate moral agents - not only violate the status dignity of their subjects, but also lose their own status dignity, thereby becoming liable to interference. In Section 5, I consider objections. Section 6 concludes.

As this brief sketch shows, my view has at least two revisionary implications. First, human rights articulate standards for respecting the status dignity of the subjects of sovereign authority, as opposed to the inherent dignity of human beings. Second, the notion of (status) dignity may be appropriately applied not only to individual agents, but also to corporate ones, like states. In particular, states that violate human rights lose their status dignity. If I am right, we have good reasons for taking these revisionary implications seriously.

Before I start, two points of clarification. First, I focus exclusively on how human rights and dignity should be understood: i.e., how they should be defined. I remain largely agnostic about the-independently important-issue of what grounds or justifies them. A core message of this article is that the definition of human rights should, as much as possible, be kept separate from their justification. Prominent conceptions of human rights go wrong precisely because they unhelpfully build a certain justification of human rights - i.e., one grounded in inherent human dignityinto their definition. ${ }^{6}$ Second, I conduct my analysis from a normative individualist

\footnotetext{
${ }^{4}$ McCrudden highlights how reference to dignity was helpful in drafting the UDHR, since 'it supplied a theoretical basis for the human rights movement in the absence of any other basis for consensus'. See McCrudden (n 3) 677. Adherents of different comprehensive moral doctrines could simply interpret dignity in their favored way. This, however, supports my worries about the emptiness of dignity and the emergence of disagreements when we try to fill it with content.

${ }^{5}$ Schroeder (n 3).

${ }^{6}$ My contrast between 'definition' and 'justification' parallels Tasioulas' distinction between 'nature' and 'grounds'. I prefer the language of 'definition', since it strikes me as less realist/essentialist. See
} 
perspective on political morality, according to which individual human beings are equal and ultimate units of moral concern.

\section{Dignity and Human Rights}

The notion of dignity is slippery. In recent years, there has been much discussion concerning its genesis and proper meaning. ${ }^{7}$ In this section, I propose a conceptual framework for thinking about dignity (2.1), and then bring it to bear on contemporary discussions about the relationship between dignity and human rights (2.2).

\subsection{Dignity}

I begin by distinguishing between two concepts of dignity: status dignity and inherent dignity.

Status dignity: a status an entity possesses, comprising stringent normative demands. ${ }^{8}$

Inherent dignity: an inherent property of an entity, possession of which is said to justify the attribution of a given status to it. ${ }^{9}$

Note that, at this abstract conceptual level, it is an open question which classes of entities possess dignity in either sense. Nothing necessitates restricting the relevant classes to human beings. Moreover, status and inherent dignity, as I understand them, are independent. For example, one may argue that non-human animals have status dignity (i.e., that there exist stringent normative standards governing their treatment)

John Tasioulas, 'On the Nature of Human Rights' in Gerhard Ernst and Jan-Christoph Heilinger (eds), The Philosophy of Human Rights: Contemporary Controversies (De Gruyter 2012) 19.

${ }^{7}$ See, e.g., Jeremy Waldron, Dignity, Rank, and Rights (Meir Dan-Cohen ed, Oxford University Press 2012); Jeremy Waldron, 'Is Dignity the Foundation of Human Rights?' in Rowan Cruft, S Matthew Liao and Massimo Renzo (eds), Philosophical Foundations of Human Rights (Oxford University Press 2015); George Kateb, Human Dignity (Harvard University Press 2011); Michael Rosen, Dignity: Its History and Meaning (Harvard University Press 2012); Christopher McCrudden (ed), Understanding Human Dignity (Oxford University Press/British Academy 2013); cf. Charles R Beitz, 'Human Dignity in the Theory of Human Rights: Nothing But a Phrase?' (2013) 41 Philosophy \& Public Affairs 259.

${ }^{8}$ I take 'status' to be synonymous with normative standing. A normative standing, in turn, can be articulated in terms of a bundle of normative standards that apply to one's and others' behaviour. Take, for example, the status of being 'a citizen', 'a parent', 'an employee', 'a friend', and so forth. Each of them is distinctive in that it is associated with specific normative standards: there are particular moral demands that apply to the actions of citizens, parents, friends (etc.), and to the actions of others towards them. For the idea of dignity as a 'status concept' and as a 'valuable status', see, respectively, Jeremy Waldron, 'Is Dignity the Foundation of Human Rights?' (n 7) 134; John Tasioulas, 'Human Dignity and the Foundations of Human Rights' (n 2) 305. Waldron, too, suggests that dignity, as a status concept, comprises a set of rights (hence of stringent normative demands) instead of providing their foundation. See Waldron, 'Is Dignity the Foundation of Human Rights?' (n 7) 134-35. Pablo Gilabert also uses the expression 'status dignity', but to designate an inherent property of humans. Hence, for Gilabert, status dignity is closer to what I call inherent dignity. See Pablo Gilabert, 'Human Rights, Human Dignity, and Power' in Rowan Cruft, S Matthew Liao and Massimo Renzo (eds), Philosophical Foundations of Human Rights (Oxford University Press 2015) 199.

${ }^{9}$ Michael Rosen distinguishes between dignity as (i) a status, (ii) an 'inner transcendental kernel', (iii) a property of actions ('being dignified'), and (iv) a requirement on the treatment of people ('treating them with dignity'). My distinction between status and inherent dignity is closest to Rosen's distinction between (i) and (ii). See Michael Rosen, 'Dignity: The Case Against' in Christopher McCrudden (ed), Understanding Human Dignity (Oxford University Press/British Academy 2013) 153-54. For other taxonomies of dignity, see Schroeder (n 3) 332; Düwell (n 1) 26; Gilabert, 'Human Rights, Human Dignity, and Power' (n 8); Gilabert, Human Dignity and Human Rights (n 2). 
by virtue of being sentient creatures. On this view, abusing non-human animals-e.g., placing a lion in a small cage - may well violate their dignity, in the sense of being at odds with the treatment demanded by their status. However, that status need not be justified by an appeal to inherent dignity. Sentience or consciousness may also play the relevant justificatory role.

Even though status dignity and inherent dignity are independent, human beings are assumed to have both. They are often said to have (what I call) status dignity by virtue of possessing inherent dignity. I will return to humans' inherent dignity in a moment. For now, let me focus on their status dignity.

The status dignity of human beings: a status human beings possess, comprising stringent normative demands.

To the extent that human beings are agents capable of moral reasoning, the relevant normative demands are twofold. They concern: (i) the treatment that human beings command from others, and (ii) the behaviour that human beings ought to live up to. Call these, respectively, passive status dignity and active status dignity. When a human being is not treated as she ought to be, we say that her status dignity is violated. When she fails to live up to the standards of behaviour that apply to her, we say that her status dignity is wholly or partly lost.

To see this, consider the following examples. By all plausible moral standards, a torturer imposing cruel and degrading treatment on an innocent violates the victim's status dignity. He fails to treat her as her status requires. In turn, by so behaving, the torturer partly loses his own status dignity: he becomes liable to forms of treatment that would not otherwise be permissible towards him-e.g., some forms of physical harm or freedom-restriction. His behaviour is at odds with what one would expect from a moral agent.

In a similar vein, individuals who develop drug addictions are often said to (temporarily) lose their (status) dignity: their dependence on alien substances, and the impact this has on their capacity for autonomy, modifies what counts as permissible treatment towards them. For example, a fair dose of paternalism towards a drug addict might be permissible, while it would be impermissible towards anyone whose capacity for autonomy and moral reasoning remain intact.

This, I suggest, is how to understand the status dignity of humans. Different substantive conceptions of this concept, in turn, can be obtained by different specifications of the normative demands associated with this status. ${ }^{10}$ In what follows, I will refrain from offering a full substantive account of those demands. I will, however, discuss how human rights in particular might, or might not, contribute to specifying them.

\subsection{Dignity and Human Rights}

Humans' status dignity and inherent dignity are brought together in debates about human rights. Human rights are often defined as standards of treatment that human beings command by virtue of their inherent dignity. In my vocabulary, they are standards for the passive status-dignity of humans, grounded in their inherent dignity.

\footnotetext{
${ }^{10}$ For the distinction between 'concepts' and 'conceptions' - though discussed in relation to justicesee John Rawls, A Theory of Justice (Oxford University Press 1999) 5, who in turn draws on HLA Hart, The Concept of Law (Clarendon Press 1961).
} 
Building inherent dignity into the definition of human rights is considered necessary to mark them out as a distinctive class of universal moral rights.

Suppose, for instance, that we all have a right not to be pushed on the street. Even so, it would be odd to suggest that if someone rudely pushed me, she would violate my human rights. A plausible explanation for this judgement is that, while being pushed is unpleasant and probably wrong, it is not an affront to my inherent dignity, and therefore does not result in a violation of the 'dignitarian' standards of treatment that are grounded in it: human rights. Similarly, being insulted by a friend may be hurtful and offensive, but we would hesitate to call it a human-rights violation, precisely because it is not an affront to one's inherent dignity as a human.

Albeit helpful at first, the conceptual connection between human rights and inherent dignity is problematic. ${ }^{11}$ Unlike status dignity, inherent dignity has metaphysical connotations. Short of 'inherent dignity' remaining an empty category, or an unexplained primitive, reference to it forces those engaged in debates about human rights to take a stand on what endows human beings with this 'inner transcendental kernel'- to use Michael Rosen's expression. ${ }^{12}$ As soon as this issue is raised, however, controversies arise.

For example, those with Kantian sympathies see inherent dignity as grounded in humans' capacity for autonomy. The trouble with this view, in a human-rights context, is that it prevents its advocates from including human beings who lack a capacity for autonomy - such as small children and those with severe mental disabilities - within the group of human-rights holders. ${ }^{13}$ Critics of the connection between dignity and autonomy might insist that inherent human dignity derives from the privileged relation between humans and God. But here, too, further disagreement is bound to arise with respect to which God is the one that matters. ${ }^{14}$ And if sentience alone bestows inherent dignity on human beings, then we should conclude that several non-human animals are also endowed with inherent dignity and are, consequently, beneficiaries of human-rights norms. ${ }^{15}$

As the previous paragraph briefly illustrates, tying human rights to individuals' inherent dignity runs the risk of turning debates about human rights into metaphysical disputes about the moral standing of humans - and, possibly, of other creatures too. This shift is lamentable: it is divisive and distracts from the distinctive political function of human rights. The contemporary idea of human rights - as expressed in the Universal Declaration - is born out of the need to create a shared set of constraints on the conduct of states and state-like entities. In the words of Charles Beitz, human rights constitute 'a public normative practice of global scope whose central concern is to protect individuals against the consequences of certain actions and omissions of their governments'. ${ }^{16}$ Importantly, this in no way deprives human rights of theoretical significance. Yet it highlights that this theoretical significance belongs to a particular domain of inquiry: the political one.

These reflections invite two immediate responses. One involves denying the political function of human rights, and welcoming definitions of human rights that breed deeper metaphysical controversies about their grounds. The other involves

\footnotetext{
${ }^{11}$ Schroeder (n 3).

12 Rosen, 'Dignity: The Case Against' (n 9) 153-54.

${ }^{13}$ Griffin (n 2).

${ }^{14}$ See Tasioulas, 'Human Dignity and the Foundations of Human Rights' (n 2), for discussion.

${ }^{15}$ Cf. Alasdair Cochrane, 'From Human Rights to Sentient Rights' (2013) 16 Critical Review of International Social and Political Philosophy 655.

${ }^{16}$ Charles R Beitz, The Idea of Human Rights (Oxford University Press 2009) 14-15.
} 
suggesting that, when thinking about human rights, we should dispense with the notion of dignity. In the remainder of this article, I argue that neither response is satisfactory. In the next section, I defend the political function of human rights, and argue that this should be reflected in our definition of human rights. In subsequent sections, I construe the conceptual relationship between dignity and human rights in a way that aids, rather than undermines, this function. Specifically, I show that, while reference to 'inherent human dignity' is unhelpful, we can retain the notion of status dignity, and interpret it so as to reinforce the political role of human rights.

\section{The Political Function of Human Rights}

Over the past decade, there has been much debate about how to define human rights. At the heart of this debate lies the controversy between so-called 'orthodox' and 'political' conceptions of human rights. The former see human rights as a special class of entitlements that all human beings possess by virtue of their humanity (or inherent dignity), vis-à-vis other moral agents suitably positioned to fulfil them: including private individuals, states, and corporations. ${ }^{17}$ The latter see human rights as standards of behaviour with a distinctively political function: placing constraints on the conduct of political institutions, especially states. ${ }^{18}$ For this second group of theorists, the duties correlative to human rights are borne by states and state-like entities. States bear primary responsibility for human-rights fulfilment, and (typically) the international community secondary responsibility-namely, it has a duty to intervene to prevent or to remedy some failures by states to fulfill their primary duties. ${ }^{19}$ Private individuals cannot, in principle, be human-rights violators. ${ }^{20}$

Behind these different approaches lie different methodological stances on how a conception of human rights should be arrived at. Orthodox theorists believe that there is a special class of universal moral rights that human beings hold by virtue of their humanity (i.e., their inherent dignity), and - not implausibly-these theorists find the label 'human rights' most appropriate for that class. ${ }^{21}$ For them, contemporary human-rights culture is ultimately concerned with this class of universal rights.

\footnotetext{
${ }^{17}$ See, e.g., Griffin (2); Tasioulas, 'On the Nature of Human Rights' (n 6); Pablo Gilabert, 'Humanist and Political Perspectives on Human Rights' (2011) 39 Political Theory 439. See note 1 for clarification on the relationship between dignity and humanity.

${ }^{18}$ See, e.g., Beitz, The Idea of Human Rights (n 16); John Rawls, The Law of Peoples: With 'The Idea of Public Reason Revisited' (Harvard University Press 1999); Joseph Raz, 'Human Rights without Foundations' in Samantha Besson and John Tasioulas (eds), The Philosophy of International Law (Oxford University Press 2010); cf. Thomas Pogge, World Poverty and Human Rights: Cosmopolitan Responsibilities and Reforms (Polity 2008); Dworkin (n 2) 332-39.

${ }^{19}$ On a related distinction between primary and secondary agents of justice, cf. Onora O'Neill, 'Agents of Justice' (2001) 32 Metaphilosophy 180. On 'remedial' responsibility-i.e., the type of human-rights responsibility often associated with the international community—see David Miller, 'Distributing Responsibilities' (2001) 9 Journal of Political Philosophy 453.

${ }^{20}$ This is a very broad characterization of these two families of views, which skips over differences in important details. For further analysis, see Tasioulas, 'On the Nature of Human Rights' (n 6); Laura Valentini, 'In What Sense Are Human Rights Political? A Preliminary Exploration' (2012) 60 Political Studies 180.

${ }^{21}$ Note that the formulation is compatible with inherent dignity being a necessary, but not a sufficient, ground of human rights. See Tasioulas, 'Human Dignity and the Foundations of Human Rights' (n 2).
} 
Theorists who embrace the political approach, by contrast, tend to hold that a conception of human rights should be faithful to human-rights practice. ${ }^{22}$ For them, the function that human rights have in the practice of human rights - as this is carried out by states, NGOs, international courts and other relevant actors - determines their conceptual domain. ${ }^{23}$ And since, in the practice, human rights are predominantly (though not exclusively) means of constraining state conduct, this is how the concept should be defined.

Which of these two approaches is most convincing? As readers might infer from my remarks in the previous section, I favour a political approach to human rights. But I also find some of the arguments typically offered in its supportspecifically, the underlying methodology-unconvincing. The fact that human-rights practitioners understand human rights in a certain way is evidence of how they conceptualize this notion, not of how human rights should be understood. After all, we want to allow for the possibility that how a given notion is understood in practice might be misleading or unhelpful. ${ }^{24}$ Yet, the methodology behind the political approach - in at least some prominent variants - appears to foreclose that possibility.

In what follows, I defend a version of the political approach to human rights, not on the basis of the priority of human-rights practice, but on the basis of broader theoretical considerations that should guide us in defining contested concepts in general, and human rights in particular. ${ }^{25}$ I first outline these theoretical considerations, and then show why they support the political approach.

\subsection{What makes for a good definition of human rights? ${ }^{26}$}

A plausible definition of human rights should meet the following desiderata.

a) Distinctive moral significance: the concept of human rights captures a distinctive moral phenomenon.

This desideratum requires that the concept of human rights pick out a moral phenomenon that is qualitatively different from others. To put the same point another way, human-rights violations must be distinctive wrongs, for which it makes sense to create a separate moral category.

b) Consistency with ordinary language use: the concept of human rights is reasonably in line with ordinary language use.

\footnotetext{
${ }^{22}$ Tasioulas, who defends the orthodox view, also embraces a 'fidelity to the practice' desideratum, though it is not clear (to me) how central a role it plays in his account of human rights. See Tasioulas, 'On the Nature of Human Rights' (n 6).

${ }^{23}$ See, esp., Beitz, The Idea of Human Rights (n 16); cf. Andrea Sangiovanni, 'Justice and the Priority of Politics to Morality' (2008) 16 Journal of Political Philosophy 137.

${ }^{24}$ Tasioulas, 'On the Nature of Human Rights' (n 6) 18.

${ }^{25}$ On contested concepts, see WB Gallie, 'Essentially Contested Concepts' (1955) 56 Proceedings of the Aristotelian Society 167.

${ }^{26}$ A good definition of human rights is not an overall philosophical theory of human rights. Elsewhere, I tried to sketch such a theory_-based on Kant's political writings - but in so doing, I blurred the lines between 'definition' and 'justification'. See Laura Valentini, 'Human Rights, Freedom, and Political Authority' (2012) 40 Political Theory 573. As this article makes clear, I now think that the two should be kept separate. For a different list of desiderata, partly overlapping with the one I am proposing (especially desideratum (a)), see Tasioulas, 'On the Nature of Human Rights' (n 6) 18.
} 
To be sure, just as the practice of human rights is not definitive of the concept, ordinary language use does not settle the question of how we should understand human rights. However, provided our definition of human rights is able to capture something of distinctive moral significance, the less it departs from how that concept is understood in ordinary language, the less confusing the definition will be. We should not recommend a radical change in how we use language unless strictly necessary.

c) Metaphysical agnosticism: the concept of human rights remains, as far as possible, agnostic with respect to disputed metaphysical views.

The final desideratum is probably the most controversial. It suggests that human rights should be defined in a way that does not already tie them to a particular metaphysical foundation. It is of course not hard to justify this desideratum to those who believe that human-rights principles should serve as the shared moral code of the international community. But, independently of human rights' role as international moral standards, metaphysical lightness is generally appropriate when we are defining a concept, rather than grounding or justifying the phenomenon the concept refers to. While metaphysics is perhaps unavoidable when trying to articulate a deep justification for human rights, it seems ill-advised to build such justification into the definition of human rights. Doing so would foreclose the possibility for people to agree on what human rights are, while disagreeing about what grounds or justifies them. ${ }^{27}$ That is, it would reduce the space for meaningful debate about the justification of human rights. $^{28}$

\subsection{Why human rights are best understood as 'political'}

Let us now adjudicate the orthodox and political approaches relative to our three desiderata. The orthodox approach has a plausible claim to capturing a distinctive moral phenomenon (a): human beings' possession of certain rights vis-à-vis all other agents by virtue of their inherent dignity. This phenomenon has been given other labels too: such as individuals' 'fundamental moral rights' or 'natural rights'. But there is no reason to worry about synonyms. To the extent that the label 'human rights' does a good job of denoting a distinctive moral phenomenon, the fact that the same phenomenon is also captured by other labels is no strong objection against the orthodox theorist's definition of human rights. By way of analogy, very few seem to be disturbed by the fact that the words 'freedom' and 'liberty' denote roughly the same object. So why should the fact that human rights and fundamental moral rights are synonyms trouble us?

The orthodox view appears less obviously successful when it comes to the other two desiderata. Its consistency with ordinary language use (b) is only partial. For example, on the orthodox view, a mother neglecting her children, a thug beating up a stranger, and a political protester preventing voters from reaching the polling station all count as human-rights violators (of, respectively, the rights to subsistence, physical integrity and voting). Although this suggestion is not implausible, it does somewhat jar with ordinary language use, which tends to reserve the term 'human-

\footnotetext{
${ }^{27}$ Cf. the notion of 'overlapping consensus' in John Rawls, Political Liberalism (Columbia University Press 1996).

${ }^{28}$ Cf. Tasioulas, 'On the Nature of Human Rights' (n 6) 20.
} 
rights violations' for wrongs of political significance. ${ }^{29}$ Consider, for example, an entirely non-political murder in an otherwise well-ordered society. The murderer clearly wrongs the victim, and thereby deprives her of one of the goods access to which is uncontroversially regarded as a human right: life. Yet we tend not to describe murders as human-rights violations - as opposed to violations of fundamental rights simpliciter.

Regarding (c), the orthodox view - in at least some versions-encounters difficulties. Some orthodox theorists tend to build a broad justification of human rights into their definition. As we have seen, human rights are characterized as universal rights that human beings hold vis-à-vis all other entities 'by virtue of their inherent dignity' or 'by virtue of their humanity'. ${ }^{30}$ The grounds in question, it should be noted, are broadly stated. In fact, they are so broadly stated that reference to them may not seem to be at odds with metaphysical agnosticism. Different theorists can still 'plug in' their preferred metaphysical view about the basis of human beings' rights-holding status: be it a capacity for autonomy, God's love, or something else. ${ }^{31}$

I am sceptical about this response. First, if 'inherent dignity' and 'humanity' are so broad that they can be interpreted in a myriad different ways, then reference to them seems superfluous: it does not tell us something useful about human rights. Second, even reference to very broad grounds - such as 'dignity' and 'humanity' invites metaphysical disputes. As soon as someone raises the questions 'Why do human beings have dignity?' or 'What is special about humanity?', we are back in the realm of deep disagreements. To satisfy desideratum (c), then, definitions of human rights should be silent on the question 'by virtue of what special intrinsic property' human beings hold those rights.

Orthodox theorists might take this suggestion on board, and remove any reference to inherent human dignity (or similar ground) from their definition of human rights. ${ }^{32}$ Human rights would then be characterized as moral rights human beings hold vis-à-vis all other suitably positioned agents simpliciter. This move would come at a cost, however: robbing human rights of their distinctiveness. Human-rights violations are distinctively wrong - on the orthodox picture we are consideringbecause they are an affront to persons' inherent dignity. Once reference to inherent dignity is removed, the distinctiveness of human rights as a moral phenomenon-as a special class of universal moral rights - starts fading away. Being rudely pushed on the street or insulted by a stranger in non-political contexts become candidates for human-rights violations. This suggests that orthodox views may either satisfy desideratum (a) or desideratum (c), but struggle to satisfy both.

Orthodox theorists may respond by trying to retain the distinctiveness of human rights without appealing to inherent properties of human beings. For instance, they could define human rights as rights that we all hold vis-à-vis any suitably positioned agent and whose function is to protect us from the most serious setbacks to our interests. On this version of the orthodox view, being culpably scratched by

\footnotetext{
${ }^{29}$ This is pointed out in Pogge (n 18) s 2.3.

${ }^{30}$ Tasioulas, 'On the Nature of Human Rights' (n 6); 'On the Foundations of Human Rights' (n 2) 292. Interestingly, Tasioulas says: 'we should resist building into the nature of human rights anything like a complete account of their grounds'. Tasioulas, 'On the Nature of Human Rights' (n 6) 20, emphasis added. The word 'complete' is important here. Tasioulas defines human rights as those humans hold 'by virtue of their humanity', thereby building a broad/incomplete account of their grounds into the definition of human rights.

${ }^{31}$ McCrudden (n 3).

${ }^{32}$ I am grateful to Timothy Endicott for raising this possibility.
} 
another in a fight is a violation of bodily integrity, but not of human rights. By contrast, being culpably stabbed and seriously injured in the same context is a humanrights abuse. In both cases, we are dealing with violations of bodily integrity. It is just that one is much worse than the other and, for this reason, it counts as a human-rights wrong.

This solution is only partially satisfactory, because it reduces the distinctiveness of human rights to the gravity of the wrong involved in violating them. Human-rights wrongs, on this view, are not qualitatively distinctive. They are just very serious. Moreover, gravity is a scalar notion, and a 'non-ad-hoc' threshold needs to be found in order to determine when a universal-rights violation is serious enough to qualify as a human-rights violation. Finding such a 'non-ad-hoc' threshold is a challenging task. Perhaps, orthodox theorists will succeed at it; but it remains the case that a gravity-based account of the distinctiveness of human-rights wrongs is less powerful than one capable of singling out human-rights wrongs as qualitatively different from other rights-violations.

Understanding human rights as proponents of the political approach do allows us to avoid the difficulties encountered in connection with orthodox approaches. Recall that, on the political approach, primary responsibility for human rights is borne by states or state-like entities, and secondary responsibility by the international community, which is called upon to intervene when states neglect their duties.

Regarding desideratum (a), on the political approach, human rights capture a qualitatively distinctive moral phenomenon, yet one that differs from the phenomenon of fundamental rights possession grounded in inherent dignity. Instead, human rights regulate the sui generis moral relationships between agents with sovereign authority and their subjects. In today's world, this type of relationship exists paradigmaticallybut not exclusively - between states and those within their jurisdiction. ${ }^{33}$

States have de facto authority, i.e., they claim and obtain obedience on the part of their subjects. Furthermore, they are sovereign, i.e., they claim and obtain noninterference on the part of outsiders: they are the final arbiters within their respective jurisdictions. These de facto privileges stand in need of justification. And they are only justified if states treat their subjects appropriately. Human rights, on the political view as I understand it, embody the relevant standards of appropriate treatment.

Regarding states as the primary bearers of human-rights responsibilities accounts for the distinctive wrong tied to human-rights violations. The authority that states enjoy is conditional on its exercise promoting subjects' good. Yet, when states violate human rights, they fail to live up to their special responsibilities, thereby perpetrating this sui generis wrong. ${ }^{34}$

By analogy, consider the special type of wrongdoing perpetrated by a parent who murders their child, compared to a stranger who murders a child unrelated to them. Both acts are, of course, deeply wrong. Yet the special authority-relationship existing between parent and child renders the act in the first case distinctively morally abhorrent. The agent specially tasked with protecting a given individual actively brings her life to an end. Similarly, consider a criminal kidnapping and torturing a helpless passer-by, and compare this wrong to that perpetrated by state officials

\footnotetext{
${ }^{33}$ The next four paragraphs draw on ideas in Laura Valentini, 'Human Rights, the Political View, and Transnational Corporations: An Exploration' in Tom Campbell and Kylie Bourne (eds), Political Approaches to Human Rights (Routledge forthcoming); and Valentini, 'Human Rights, Freedom, and Political Authority' (n 26) 587-88.

${ }^{34}$ See, e.g., Christian Barry and Nicholas Southwood, 'What Is Special About Human Rights?' (2011) 25 Ethics \& International Affairs 369.
} 
arbitrarily detaining political opponents in degrading conditions. ${ }^{35}$ Although both acts are gravely wrong, the latter appears distinctively wrong-even if we assume that the material effects on the victims are the same in both cases - and this is because of the authority relationship between states and their subjects.

Relatedly, sovereignty gives us an explanatory entry-point for why humanrights violations are distinctive in triggering international concern. ${ }^{36}$ They do so because the de facto non-interference that sovereign agents, such as states, enjoy is morally conditional on their performing certain services for their subjects. When those services are not performed, external concern is entirely appropriate; in the same way in which, when parents neglect or abuse their children, external concern - on the part of other families, or the state itself-is also appropriate.

As we have seen, on (my version of) the political approach, human rights designate a distinctive moral phenomenon. Yet, unlike in the case of the orthodox view, it is hard to come up with synonyms for it. While we may easily replace the orthodox idea of human rights with the notion of fundamental moral rights, no such replacement appears available for the phenomenon captured by the political idea of human rights. This may give us some reason for understanding human rights in line with the political approach. Our reasons for doing so will be further strengthened by considering the other two desiderata.

The previous discussion should already illustrate how the political approach has a good claim to meeting 'consistency with ordinary language use', at least when it comes to core instances of the use of human-rights language (b). By definition, on a political approach, human-rights violations can only be perpetrated by sovereign and authoritative entities: so private murders are not human-rights violations, while state executions of political opponents are.

It may be objected that, contrary to common use, on the political view, only citizens of a given state $\mathrm{S}$ may have their human rights violated by $\mathrm{S}$. A tyrannical state arbitrarily imprisoning a group of tourists would not be violating their human rights - which seems counter-intuitive. This conclusion is not quite correct. While citizens may in fact be subjected to particularly extensive state authority, residents as well as tourists who find themselves on a state's territory are also subjected to its authority - though across a narrower set of domains (e.g., tourists might not have to pay income tax). To that extent, classes of individuals other than citizens may also be, in principle, the victims of human-rights violations on the political approach I am proposing. $^{37}$

Finally, turning to desideratum (c), the political approach to human rights helpfully avoids metaphysical controversies. It defines the notion of human rights without tying it to any particular conception of the individual; it ties it rather to a particular conception of duty-bearers. Why, exactly, human beings have human rights

\footnotetext{
${ }^{35}$ See Pogge (n 18) 66.

${ }^{36}$ Beitz, The Idea of Human Rights (n 16).

${ }^{37}$ An anonymous reviewer has pointed out that, in Canada, anti-discrimination law applying to private employers is described as human-rights law. If so, the political approach jars with some ordinary language use. I concede that the approach does not capture all instances of ordinary-language use. This, however, is not a vice of the approach, insofar as consistency with ordinary language use matters only to the extent that it is compatible with the term 'human rights' capturing a distinctive moral phenomenon, and the expression 'human-rights violations' a distinctive wrong. The political approach, by focusing on the rights of subjects vis-à-vis sovereign authorities, meets the distinctiveness desideratum, and displays good consistency with core instances of ordinary language use. Extending the notion beyond those core instances - e.g., to denote the rights of employees vis-à-vis employers, or of private individuals vis-à-vis each other-would rob it of its moral distinctiveness.
} 
against entities with authority over them remains an open question, and different political-moral traditions may answer it differently. Furthermore, on the political approach, leaving that question open does not undermine human rights' ability to capture a distinctive moral phenomenon: the distinctive wrong perpetrated by sovereign entities who abuse or misuse their power over their subjects.

The foregoing analysis, I believe, lends plausibility to the view that the duties correlative to human rights are held by sovereign and authoritative political agents (primarily states) vis-à-vis those subjected to their rule. This allows us to capture the qualitatively distinctive wrong of human-rights violations, while retaining a good level of consistency with ordinary language use and avoiding metaphysical quandaries. To be sure, the debate between orthodox and political views is on-going, and my arguments are unlikely to be conclusive. Still, they should at least offer considerations in favour of taking the political nature of human rights seriously. Next, I explore how human rights so understood relate to the notion of status dignity articulated in Section 2.

\section{Dignity, Human Rights, and Sovereign Authority}

A political approach to human rights, such as the one I have articulated, may seem to have no room for the notion of dignity. This appearance, however, is not quite correct. While it is true that, on my view, definitions of human rights should stay clear of references to inherent dignity, nothing I have said speaks against drawing a conceptual connection between human rights and status dignity. The present section is devoted to developing precisely that connection.

Human rights, from a political perspective, do not articulate standards for respecting the dignity of individuals qua human beings. Instead, they set out:

i. universal standards for respecting the passive status dignity of subjects of sovereign authorities qua subjects, and

ii. universal standards that sovereign authorities must respect in order not to lose their own active status dignity qua sovereign authorities.

This way of conceptualizing human rights, and their connection to status dignity, is revisionary in two respects.

1. It implies that normative standards of dignity may be held not only by virtue of one's intrinsic or inherent properties (e.g., being a sentient creature; being a creature capable of autonomy, being a creature with inherent dignity), but also by virtue of one's relational properties (e.g., being the subject of a sovereign authority).

2. It implies that not only individuals, but also corporate entities-like statesmay have status dignity.

Undoubtedly, (1) and (2) will breed scepticism about the viability and merits of the proposed way of conceptualizing the relationship between dignity and human rights. Upon further scrutiny, however, implications (1) and (2) are far from sinister; in fact, they are quite plausible and reinforce the role of human rights as standards for limiting state (and state-like) power. I now discuss them in turn. 


\subsection{Dignity beyond humanity alone}

I have characterized status dignity as a particular standing an entity holds, while remaining agnostic about the properties by virtue of which this status may be held. Typically, the 'property' parameter is filled by some intrinsic quality of the individual: what Rosen calls an 'inner transcendental kernel'. ${ }^{38}$ As we have seen, reference to such intrinsic properties opens the door to divisive metaphysical controversies.

It is not clear, however, why only intrinsic properties may be grounds of status dignity, and not also relational ones. The former are properties that a particular entity has independently of how it relates to its context; the latter are properties that depend on an entity's relationship to its context. ${ }^{39}$ For instance, the following properties of an individual - being two meters tall, being a biological female, being sentient-are intrinsic, or 'non-relational'. By contrast, the following properties - being the richest person in town, being taller than someone else, being the subject of a given political authority, being the Prime Minister-are relational.

There are good reasons for considering relational properties as possible grounds of status dignity. After all, we routinely assume that different standards of treatment apply to different agents depending on the particular relationships in which they stand vis-à-vis each other: professional relationships, family relationships, friendships and so forth. This is also reflected in our judgements about dignity.

For instance, we can plausibly claim that a boss who makes fun of one of his employees-Joe-violates Joe's status dignity, and this by virtue of the particular relationship in which the two stand vis-à-vis each other. The boss's mockery is inappropriate towards Joe qua employee. The mockery demeans and degrades Joe, and represents an abuse of power on the part of his employer. But note that Joe would not have his status dignity violated if his best friend made exactly the same joke in a different context: a gathering between 'old mates' where they all laugh and make fun of each other. The treatment Joe is owed qua friend differs from the treatment he is owed qua employee. And our judgements about dignity track this variation. Indeed, we may plausibly distinguish between different types of status dignity depending on the particular role one occupies. We can talk about one's status dignity as a friend, family member, professional colleague, member of the human community, and so forth.

In line with these observations, the treatment an individual is owed qua human may plausibly differ from the treatment she is owed as a subject of a given political authority. While nobody should kill innocent people, lie or torture others, individuals are owed access to certain fundamental freedoms and material goods primarily by the sovereign entities claiming authority over them. And when these authorities fail to act on the relevant standards of behaviour, a distinctive dignity-related wrong occurs.

Consider the following example. My failure to provide secure access to basic socio-economic goods to two distant needy people, call them Mary and Bob, does not imply a violation of their status dignity on my part. I may have the resources to assist them, but decide to invest them in other charitable causes, which will instead help Kirsten and Alan: two of the poor in my own community. Mary's and Bob's status dignity does not seem to be violated by my decision.

\footnotetext{
${ }^{38}$ Rosen, 'Dignity: The Case Against' (n 9) 153-54.

${ }^{39}$ Franz Dietrich and Christian List, 'Reason-Based Choice and Context-Dependence: An Explanatory Framework' (2016) 32 Economics \& Philosophy 175.
} 
Things would be very different if the state claiming authority over Mary and Bob neglected their needs, and instead devoted resources to improving the life conditions of non-subjects or, more plausibly, to filling the pockets of corrupt officials. In those cases, Mary's and Bob's state would violate their status dignity, by deeming them not worthy of the special concern they are entitled to qua subjects. The power conferred on the state to serve the interests of people like Mary and Bob is misused to serve the interests of others. In this example, the existence of an authority relationship opens up the possibility for dignitarian wrongs that could not occur in the absence of such a relationship.

True, dignity-violations can also occur at the hands of private persons. But those violations are qualitatively different from those occurring at the hands of authorities. Let us go back to the case of a criminal kidnapping and torturing an innocent bystander, and compare this with state officials arbitrarily detaining political opponents. ${ }^{40}$ In both cases, we are faced with status-dignity violations. In the first case, we can say that the kidnapper violates the status dignity of her victim as a human being: the normative demands that govern the treatment of humans. In the second case, however, something else appears to be going on. The power given to officials to protect their subjects is used to oppress them. Their status dignity is thus violated not only as human beings, but also, and crucially, as subjects, betrayed by those who ought to safeguard their interests.

The upshot of this discussion is that we have independent reasons for regarding standards of status dignity as partly dependent on relational properties, and thus as varying from context to context. What is more, our judgments about the dignity of subjects track our judgements about human rights. While my helping Kirsten and Alan does not violate Mary's and Bob's human rights, neglect on the part of their government does. And the same conclusions apply in relation to the kidnapping and arbitrary detention cases. Taken together, these observations support my proposal that human rights set standards for honouring the passive status dignity of individuals qua subjects of authority.

\subsection{Human rights as standards for the active status dignity of corporate entities}

On the view I have outlined, it makes sense to speak about the status dignity of states, and of corporate entities more generally. ${ }^{41}$ For some, this will be a step too far. Dignity is a status that only individuals, qua ultimate units of moral concern, carry. Claiming that states, and state-like entities, may be holders of status dignity - so the objection goes - commits one to the problematic view that not only individuals but also groups are ultimate units of moral concern.

This is not quite right. Speaking about the status dignity of corporate entities, and in this specific case of sovereign states, does not commit one to a collectivist account of ultimate moral worth. Instead, it provides us with a richer vocabulary with which to regulate the conduct of those entities.

To see this, I begin by noting that status dignity should not be confused with inherent dignity. While the latter is typically associated with intrinsic moral worth, ascription of status dignity simply signals that a set of stringent normative demands

\footnotetext{
${ }^{40}$ See the similar example in Pogge (n 18) 66.

${ }^{41}$ On corporate agency see, e.g., Christian List and Philip Pettit, Group Agency: The Possibility, Design, and Status of Corporate Agents (Oxford University Press 2011); Peter A French, Collective and Corporate Responsibility (Columbia University Press 1984); Raimo Tuomela, Social Ontology: Collective Intentionality and Group Agents (Oxford University Press 2013).
} 
apply to the treatment of an entity and, if the entity is a moral agent, to its conduct. So, an ascription of status dignity does not imply an ascription of intrinsic worth.

This point parallels a line of reasoning familiar from discussions of rights. It is perfectly possible to both hold that corporate entities have rights and duties and trace the justification of these rights and duties back to how corporate entities serve the interests of individuals. ${ }^{42}$ Consider voluntary corporate entities, such as clubs and associations. We typically regard them as holders of rights and bearers of duties, but the ultimate justification for their rights-holding status is that clubs and associations contribute to their members' pursuit of their life-plans. They are, in an important sense, an expression of their members' agency. Equally, we routinely hold that states have a right against third-party interference, conditional on their respecting particular standards of conduct vis-à-vis individuals and other states. This conditionality, in turn, is justified by appeal to the way in which conferring sovereign privileges on states furthers the interests of individuals. The justification of these privileges is individualistic.

We thus have no difficulties in reconciling the attribution of rights to corporate agents - i.e., the claim that they are owed a certain treatment-with a normative individualist moral outlook. This being so, it is unclear why any problems should arise when we turn to the notion of status dignity, and apply it to corporate moral agents, like states.

The active status dignity of a state, namely of a sovereign authority, depends on its acting in accordance with a relevant set of standards, including human-rights standards governing the relationship between the authority and its subjects. But human rights are not the exclusive determinants of a state's active status dignity. In addition to human rights, there are the standards of conduct that states must honour in their relations to non-subjects, namely individuals and corporate entities that do not fall within their jurisdictions. A state that violates human rights, or that engages in international aggression, loses part or all of its status dignity. It no longer commands the type of treatment typical of a sovereign authority. For example, it may no longer legitimately claim obedience on the part of its subjects (authority), and noninterference on the part of outsiders (sovereignty). ${ }^{43}$

Conversely, a state's status dignity is violated when it is attacked, subject to ridicule, or bullied by other states or even its own subjects. As the United States Supreme Court declared in 2002: 'the purpose of state sovereign immunity is to accord States the dignity that is consistent with their status as sovereign entities'. ${ }^{4}$ When a state's (legitimate) sovereignty is violated, a wrong is committed against it. But what ultimately explains this wrong, from a moral point of view, is the way in which the state in question relates to, and serves, the interests of individuals-e.g., by protecting their human rights, and contributing to a peaceful and just international order.

\footnotetext{
${ }^{42}$ List and Pettit (n 41) ch 8.

${ }^{43}$ Moral 'inability' to claim non-interference and obedience is necessary but not sufficient to justify disobedience and/or interference. Furthermore, the notion of interference should not be interpreted narrowly: it includes not only military intervention (which may be justified only in extreme cases), but also diplomatic sanctions and public criticism.

${ }^{44}$ Cited in Julie Chi-hye Suk and Judith Resnik, 'Adding Insult to Injury: Questioning the Role of Dignity in Conceptions of Sovereignty' (2003) 55 Stanford law review 1921, 1923. The Supreme Court, in this passage, was referring to immunity from private lawsuits in particular. The relation between dignity and sovereignty has international implications too, as Suk and Resnik, ibid 1958-60, also note.
} 
References to state dignity, even if they do not always track my proposed use of this notion, are not uncommon in public discourse. For example, the Mayor of Sderot, a city in Israel frequently targeted by rockets launched from Gaza, is reported to have made the following remark: 'The State of Israel has lost its dignity. Yes, countries have dignity, too. Any country that allows its sovereignty to be violated 50 times a day will eventually wither and fall'. ${ }^{45}$ The Mayor was lamenting what he took to be Israel's insufficient response to rocket attacks on the city. Similarly, in connection with the killing of Osama Bin Laden by American forces in Pakistan, which took place without Pakistan's involvement and gave rise to suspicions that the Pakistani government had been protecting Bin Laden, Imran Khan (the Pakistani cricketer and politician) declared 'Pakistan has lost its dignity' ${ }^{46}$ Finally, when the progressive party Syriza won the general elections in Greece in January 2015, Forbes Magazine published a piece titled 'Syriza's victory: Restoring the Dignity of Greece'. ${ }^{47}$ The idea was that Syriza would inaugurate a new era for the country, which would remedy both Greece's corruption-driven dignity loss and, above all, its dignity violation at the hands of third parties imposing austerity policies.

Applying the concept of status dignity to states may be unusual among scholars of dignity and human rights, but as just illustrated, it is not unusual in political discourse. ${ }^{48}$ To be sure, there, states' dignity is often seen as a function of their sovereignty, power, and international standing. Externally imposed human rights obligations may even be perceived as contrary to it. This, however, only suggests that the de facto conception of states' status dignity prevalent in the international realm is morally mistaken. This article offers theoretical considerations in support of linking states' (active) status dignity not to sovereignty and power-politics, but to humanrights standards.

This, I hasten to point out, does not commit us to the absurd conclusion that states have human rights themselves. As explained earlier, human rights set standards for the passive status dignity of subjects of sovereign authorities, and are (part of) the standards determining the active status dignity of such authorities. The passive status dignity of sovereign authorities, by contrast, may not plausibly be articulated in terms of human rights. Although this is not our topic, we may reasonably hypothesize that respecting the passive status dignity of states requires obedience on the part of their subjects, and respect on the part of non-subjects, be they private or other sovereign entities.

In sum, acknowledging the dignity of states - in the 'status' sense-is, on reflection, theoretically warranted and rhetorically advantageous: it is consistent with normative individualism and does not commit us to absurd conclusions.

\footnotetext{
${ }^{45}$ Amir Mizroch, 'Sderot Mayor: State of Israel Has Lost Its Dignity' The Jerusalem Post (Jerusalem, 26 February 2008) <http://www.jpost.com/Israel/Sderot-mayor-State-of-Israel-has-lost-its-dignity> accessed 31 March 2016, emphasis added.

${ }^{46}$ Imran Khan, 'Pakistan Has Lost Its Dignity and Self-Esteem' The Independent (London, 3 May 2011) <http://www.independent.co.uk/voices/commentators/imran-khan-pakistan-has-lost-its-dignityand-self-esteem-2278033.html> accessed 31 March 2016.

${ }^{47}$ Frances Coppola, 'Syriza's Victory: Restoring The Dignity Of Greece' Forbes (Jersey City, 27 January 2015) <http://www.forbes.com/sites/francescoppola/2015/01/27/syrizas-victory-restoring-thedignity-of-greece/> accessed 31 March 2016.

${ }^{48}$ Things are changing, however, as more scholars are starting to apply moral vocabulary most readily associated to individuals also to corporate entities. For an interesting example involving 'integrity', see Shmuel Nili, 'Liberal Integrity and Foreign Entanglement' (2016) 110 American Political Science Review 148. For a discussion broadly sympathetic to the idea that states may have dignity, see Suk and Resnik (n 44).
} 
Let me take stock. I have argued that human rights are:

- universal standards for respecting the passive status dignity of subjects of sovereign authorities, and

- universal standards for the active status dignity of sovereign authorities.

I have suggested that, in spite of its revisionary nature, this view has several virtues. I am sure that objectors will be quick to highlight its perceived vices, which I discuss below.

\section{Objections}

Let me consider two classes of objections against my reconceptualization of the relationship between dignity and human rights. One class focuses on my understanding of dignity, the other on my notion of human rights.

\subsection{Dignity}

Two complaints might be raised in relation to my discussion of dignity, in the 'status' sense. First, it might be objected that since, on my account, dignity is not inalienable, my account is problematic. Is it plausible to hold - an objector could ask-that persons may lose their entitlement to not being killed, maimed, or tortured? Does this way of thinking about dignity not make a mockery of the sanctity of life in general, and of human life in particular? I believe not.

First, recall that status dignity is only one concept of dignity; the one that, I have argued, is most fruitfully employed in discussions about human rights. While status dignity, conceptually, may be lost, this is compatible with inherent dignity being inalienable. My conceptualization of dignity is thus consistent with the inalienability of dignity as an inherent property of individuals. My only claim is that references to inherent dignity should not feature in the definition of human rights.

Furthermore, there are good reasons for regarding status dignity as alienable. To see this, it suffices to consider a notion often invoked in discussions of rights generally, where rights are - as we have seen-intimately connected to the idea of dignity: rights forfeiture. While, by default, we tend to regard human beings as holders of rights, which in turn demands that they be treated in particular ways, we also acknowledge that these claims to appropriate treatment may sometimes be lost. This occurs when individuals fail to live up to the standards of behaviour required of them. For instance, a culpable attacker may forfeit his right against being injured, and his right to a wide set of freedoms (e.g., he may be imprisoned without his rights being thereby violated), at least for a certain period of time. ${ }^{49}$ Denying the possibility of rights forfeiture would commit us either to concluding that law enforcement is impermissible because it violates rights, or to watering down the notion of rights so much as to render it empty. It would make little sense to say that imprisoning a criminal violates his right to freedom, but it is nonetheless justified for the greater good of society'. This is not a claim that a plausible normative individualist morality can accept. ${ }^{50}$

But if we have reason to acknowledge the possibility of rights forfeiture, and if rights are an important form taken by requirements of dignity, then we must accept

\footnotetext{
${ }^{49}$ Christopher Heath Wellman, 'The Rights Forfeiture Theory of Punishment' (2012) 122 Ethics 371.

${ }^{50}$ Cf. Griffin as discussed in Tasioulas, 'On the Nature of Human Rights' (n 6) 24.
} 
that dignity, in the status sense, might be at least partly lost or forfeited as well. ${ }^{51}$ In fact, our ordinary language has no difficulty in capturing this idea: one often hears expressions such as 'you have lost your dignity'. Furthermore, it is important to bear in mind that the loss of status dignity, just like the loss of a right, does not automatically imply the permissibility of harsh treatment. We may continue to have duties not to harm others even when, due to their immoral behaviour, they have (temporarily) lost much of their status dignity and forfeited their right not to be harmed.

The second objection expresses general scepticism about dignity as a category in our moral discourse. ${ }^{52}$ Here, a critic might protest that, on my framework, the notion of dignity adds nothing to the discussion of human rights. Why? Because saying that a state violates the status dignity of its subjects is equal to saying that it violates the subjects' human rights. And saying that a state has lost its status dignity is equivalent to saying that it has failed to live up to the key moral demands that apply to it, including (but not limited to) human rights. Reference to status dignity is thus redundant. $^{53}$

This objection may have some bite in the case of inherent dignity, but not, I argue, in relation to status dignity. To see this, let me draw an analogy with another contested and value-laden concept: justice. Different theorists famously disagree about what justice demands. Take John Rawls's work. ${ }^{54}$ His principles-i.e., equal basic liberties, fair equality of opportunity and the difference principle - are said to set out demands of justice. Now imagine someone objecting to Rawls on the grounds that calling his principles 'a matter of justice' is redundant: it adds nothing to the discussion. Rawls already tells us that his principles set out rights and duties, so what do we gain by saying that they are standards of justice?

I am not aware of this objection having been raised against Rawls; and it does sound quite artificial in his case. But note that it is structurally identical to the popular objection about the emptiness of dignity, which laments that adding the label 'standards of dignity' to human rights is pointless.

The addition of these labels is pointless neither in Rawls's case, nor in that of human rights. With respect to Rawls, what does 'justice' add? Reference to justice gives us an immediate sense of the particular conceptual domain in which his principles are situated. Those principles are about citizens' entitlements, and their violation is an important matter of right, an injustice: not a failure of charity, benevolence or other virtues.

A similar point applies to the notion of dignity. Talk of the 'dignity of subjects' signals that we are in the portion of conceptual space concerning the standing of individuals vis-à-vis authorities, and are focusing on the most stringent standards regulating the relationships between them: those that prohibit misuses of power of the former against the latter. Even if principles of justice, too, regulate those relationships, only some injustices also violate the dignity of subjects, since only some injustices count as instances of power misuses or abuses on the part of those authorities.

${ }^{51}$ Cf. Gilabert, Human Dignity and Human Rights (n 2).

52 See, e.g., Steven Pinker, 'The Stupidity of Dignity' [2008] New Republic $<$ https://newrepublic.com/article/64674/the-stupidity-dignity> accessed 1 April 2016; Ruth Macklin, 'Dignity Is a Useless Concept' (2003) 327 British Medical Journal 1419; cf. Rosen, 'Dignity: The Case Against' (n 9).

${ }^{53}$ Cf. the discussion in Waldron, 'Is Dignity the Foundation of Human Rights?' (n 7) 134-35.

${ }^{54}$ Rawls, A Theory of Justice (n 10). 
For instance, by Rawlsian standards, a violation of the difference principle is an injustice. But a state that failed to satisfy the demands of this principle, while still upholding its citizens' civil and political liberties and providing for their socioeconomic needs, would not count as violating their dignity. It would not be abusing its power, and neglecting its responsibilities towards its subjects. Instead, it could be plausibly interpreted as fulfilling those responsibilities in good faith, especially since there is reasonable disagreement even about whether a state should follow Rawlsian standards in order to be perfectly just. ${ }^{55}$ By contrast, a violation of the right to physical integrity on the part of one's state is not only an injustice, but an offence to a subject's dignity, a clear misrecognition of her worth as someone with a special status vis-à-vis the authority.

Characterizing a human-rights violation as a violation of the status dignity of subjects allows us to intuitively and clearly convey the distinctive wrong they represent, just as characterizing a violation of the difference principle as an injustice gives us an immediate sense of the type of wrong being committed. Similarly, when we say that a state has lost its status dignity we concisely tell our interlocutor that it has failed to live up to the most stringent standards of appropriate behaviour applying to it as a sovereign authority.

Far from being redundant, then, the language of dignity-just like the language of justice - is informative and rhetorically powerful.

\subsection{Human rights}

My account of human rights is likely to be criticized for being too restrictive because, on this account:

i. states can violate only the human rights of their subjects, while we may want to say that they can also - in principle-violate the human rights of nonsubjects;

ii. only states, and no other corporate entity, may in principle violate human rights.

I consider each of these concerns in turn. First, it is true that, on my account, states can only violate the human rights of those who are subject to their authority. It is unclear, however, whether this is such a damaging problem for the account. To be sure, states can perpetrate very serious wrongdoing against individuals who are not their subjects, such as, for instance, innocent foreign civilians during wars. But this wrongdoing is arguably different from the wrong perpetrated by a state against its subjects. The latter wrong is distinctive and adequately captured by the notion of human rights. A state's violating the rights of innocent non-subjects is a wrong that may be adequately captured by appeal to, for example, the ethical principles that govern the conduct of war, and fundamental moral — as opposed to human — rights more generally.

Second, one might get the impression that, on my account, only states may be bearers of primary human-rights duties. This impression, however, is not quite correct. On my account, primary bearers of human-rights duties are capable sovereign authorities. Not all states are capable sovereign authorities, and there exist 'de facto'

\footnotetext{
${ }^{55}$ A similar test for whether a state respects human rights-i.e., whether its behaviour can be interpreted as a good-faith attempt to respect its citizens' dignity-is proposed in Dworkin (n 2) 332 39.
} 
sovereign authorities other than states. For example, on the view I defend, some very powerful transnational corporations in areas of weak governance may qualify as bearers of human-rights responsibilities. ${ }^{56}$ Similarly, powerful supranational institutions that hold sovereign authority in relation to particular issue-domains (think of the European Union, for instance) may qualify as bearers of human-rights responsibilities. In sum, while my account is restrictive in that it makes primary human-rights duties conditional on one's status as a capable sovereign agent, it is not fundamentally statist, and therefore less restrictive than it might at first seem. ${ }^{57}$

\section{Conclusion}

In this article, I have explored the connection between dignity and definitions of human rights, and proposed a novel way of drawing that connection. I have offered arguments in support of a political approach to human rights, and argued that human rights are standards for: (i) the active status dignity of sovereign authorities and (ii) the passive status dignity of the subjects of sovereign authorities. Although this conclusion is revisionary, I have tried to show that there are good reasons in support of it.

Of course, my discussion has left the question of what grounds human rights largely unaddressed, apart from implying that a relationship of subjection is a necessary condition for one to hold such rights. ${ }^{58}$ A comprehensive philosophical theory of human rights - as opposed to an account of the concept and its connection to the idea of dignity - will have to say more about grounds. Arguably, subjection is not enough.

But the missing ingredient in a full justificatory account of human rights brings us back to those fundamental metaphysical disputes which, I have suggested, definitions of human rights should avoid. That is, it brings us back to the question of what explains human beings' ultimate moral status. This is an old, and unresolved, philosophical question: one that has repercussions not only for human rights, but for a large class of key political concepts, including justice, authority, and democracy. And if sophisticated analyses of different conceptions of justice, democracy and authority have been produced without the underlying metaphysical disputes being resolved, one would hope that the same can also occur in the case of human rights.

\footnotetext{
${ }^{56}$ David Karp, Responsibility for Human Rights: Transnational Corporations in Imperfect States (Cambridge University Press 2014); Valentini, 'Human Rights, the Political View, and Transnational Corporations: An Exploration' (n 33).

${ }^{57}$ An anonymous reviewer has objected that the link between human-rights obligations and sovereign authority is unconvincing. On the reviewer's view, what explains the wrong of human-rights violations are the power abuses suffered by victims - independently of whether the perpetrators are sovereign authorities. The difficulty with this suggestion is that the category of being 'a victim of a power abuse or misuse' is too capacious to give human-rights wrongs the required distinctiveness. Virtually all rights-violations may be described as abuses of de facto power (consider the case of the kidnapper discussed earlier). So while I agree that abuses of power are wrongful, I hesitate to call all of them human-rights wrongs. It is abuses of power against subjects perpetrated by sovereign authorities-i.e., by entities whose power is justified for the sake of those subjects - that may be appropriately termed human-rights violations.

${ }^{58}$ In this sense, my view connects with Hannah Arendt's idea that human rights presuppose some form of political membership. See her discussion of 'the right to have rights' in Hannah Arendt, The Origins of Totalitarianism (new ed with added prefaces, Harcourt Brace Jovanovitch 1968) ch 9.
} 